\title{
GEOINFORMATION SUPPORT OF TOURIST AND RECREATION DEVELOPMENT OF CULTURAL LANDSCAPE OF THE REPUBLIC OF MORDOVIA (RUSSIA)
}

\author{
Anatoliy A. YAMASHKIN \\ National Research Ogarev Mordovia State University, Faculty of Geography, Saransk, Russia, e-mail: yamashkin56@mail.ru \\ Stanislav A. YAMASHKIN* \\ National Research Ogarev Mordovia State University, Faculty of Geography, Saransk, Russia, e-mail: yamashkinsa@mail.ru \\ Milan M. RADOVANOVICH \\ Geographical Institute "Jovan Cvijič, Serbian Academy of Sciences and Arts (SASA), Belgrade, Serbia; \\ South Ural State University, Institute of Sports, Tourism and Service, Chelyabinsk, Russia, e-mail: m.radovanovic@ gi.sanu.ac.rs \\ Svetlana A. MOSKALEVA \\ National Research Ogarev Mordovia State University, Faculty of Geography, Saransk, Russia, e-mail: moskaleva-s-a@yandex.ru \\ Oleg A. ZARUBIN \\ National Research Ogarev Mordovia State University, Faculty of Geography, Saransk, Russia, e-mail: oleg-zarubin@list.ru

\begin{abstract}
Citation: Yamashkin, A.A., Yamashkin, S.A., Radovanovich, M.M., Moskaleva, S.A., \& Zarubin, O.A. (2021). GEOINFORMATION SUPPORT OF TOURIST AND RECREATION DEVELOPMENT OF CULTURAL LANDSCAPE OF THE REPUBLIC OF MORDOVIA (RUSSIA). GeoJournal of Tourism and Geosites, 37(3), 873-879. https://doi.org/10.30892/gtg.37318-720
\end{abstract}

\begin{abstract}
Study is aimed at solving the problem of developing a strategy for the formation and arrangement of cultural landscapes in the Republic of Mordovia on the basis of geoinformation support for the tourist and recreational development of the cultural landscape. The study of the formation of cultural landscapes of the region was carried out through the use of databases of spatio-temporal organization of geosystems and cartographic modeling of the patterns of economic development of geosystems. The regional GIS "Mordovia" and geoportal "Natural and Historical Heritage of the Republic of Mordovia" developed by the authors contain an interactive system of thematic maps and databases that reveal the peculiarities of nature, population, economy, cultural heritage, and the development of environmental situations of the region. The article shows that the cultural landscapes of Mordovia were formed in the process of centuries-old economic development of geosystems, and include high landscape diversity, cultural objects of peoples with unique development paths as the most important components.
\end{abstract}

Key words: cultural landscape, geoinformation support, geosystems, GIS, tourism

\section{INTRODUCTION}

A distinctive feature of the tourism industry development is a great need for a variety of geographical information about the territory that reveals the features of the main tourist sites and their surroundings accessible to travelers through the route system. World practice shows that the promotion of tourist products is currently largely determined through the design and development of regional geoportals, the information resources of which are formed in compliance with the genetic, historical and structural principles (Terkenli, 2001; Dunets, 2019). Geographical analysis of the territory economic development over centuries and identification of changes in the state of cultural landscapes are the most important direction in the study of ethnic groups' life support systems, the regularities of geosystems transformation, identifying the features of natural and historical heritage formation, forecasting the development of ecological, socio-economic processes (Hall and Page, 2014). The results of the study form a holistic view of the region significantly refine the assessment of tourist and recreational potential (Gordon, 2018). The cultural landscape is continuous, but there are central, nodal, peripheral and border elements. One of the most important of them is the settlement - a consciously altered natural landscape to create an environment of rational, efficient and healthy life. In the process of economic development, settlements form settlement systems (Ringer, 2013). The content of this concept is very capacious. It includes settlement as a process of territorial distribution of the population and because of this process - settlement in the form of areas of settlement, characterized by the number, size, population, density, functional types of ethnic groups' settlements, united by a network of various inter-settlement connections.

The natural landscape, the settlement system and the accompanying man-made elements that provide the life support system are formed in the process of territory's economic development. V.L. Kagansky writes "Any terrestrial space, the living environment of a sufficiently large (self-preserving) group of people is a cultural landscape, if this space is both integral and differentiated, and the group has mastered this space utilitarily, semantically and symbolically" (Kagansky, 2001, p. 24). For different social groups, there is the scale of the cultural landscape - the comprehension of the territory 
perceived visually or speculatively. Dominant scales are associated with the lifestyle of groups or individuals. "The multiscale nature of the landscape corresponds to the multi-scale nature of the groups of people living in it. Different groups base their life understanding and behavior on the interpretation and semantic use of different scales" [ibid., p. 33].

While analyzing cultural landscape, the prerequisites are set for a critical assessment of the conditions for the ecological, socio-economic development of regions and making adequate management decisions to optimize them. The processes of economic development are selective, and therefore the formation of cultural landscapes is metachronous, which is determined by the peculiarities of the geographical location, the nature of the surrounding natural landscape, its resource potential, transport infrastructure, material and spiritual culture of the population (Yamashkin, 2008). These factors work differently at the regional and local levels and as a result, their hierarchical systems are formed. The older they are, the more sharply the peculiarities of the interaction of environmental, economic and demographic processes are manifested (Adhika and Putra, 2020). This study is aimed at solving the problem of developing a strategy for the formation and arrangement of cultural landscapes in the Republic of Mordovia on the basis of geoinformation support for the tourist and recreational development of the cultural landscape, based on the use of geographical information about the territory, systematized on the basis of the doctrine of cultural landscapes. The solution to this problem is based on the development of digital maps and databases spatio-temporal organization of geosystems as a basis for livelihood and development of cultural landscapes.

\section{MATERIALS AND METHODS}

The study of cultural landscapes formation is a set of measures to collect, accumulate, analyze and systematize data on the development and state of life support systems (Vos and Meekes, 1999). This problem is effectively solved by means of using digital infrastructures of spatial data, providing the following directions of research development:

1) development of digital maps systems and databases of spatio-temporal organization of geosystems as the basis for the population's life support;

2) cartographic modeling of patterns of geosystems economic development and the identification of limiting factors in the development and change of cultural landscapes.

\section{Regional GIS and geosystems digital map as a base to study the cultural landscape evolution}

The regional GIS "Mordovia" and the integrated geoportal "Natural and Historical Heritage of the Republic of Mordovia" (https://tourismportal.net/) contain an interactive reference system of thematic maps and databases that reveal the peculiarities of nature, population, economy, cultural heritage, and the development of environmental situations (Yamashkin et al., 2020). The work of Begovatkin (2017) was used to reconstruct the early stages of economic development of the region. The central element of GIS is a synthetic map of geosystems (Sochava, 1978), among the advantages of which is the ability to synthesize different levels of information about interaction nature of natural, social and economic processes. Its use expands the possibilities to optimize the development of analytical maps of interaction peculiarities between nature and society. The synthetic map is focused on the allocation of geosystems hierarchy according to the classification of V.A. Nikolaev (2000):

- systems (subsystems) - distinguished by macroclimate features (arctic, subarctic, boreal, etc.), defining features of the structure development, geosystems' dynamics, functioning and development and the processes of territory's economic development;

- geosystems' classes (subclasses) - macroforms of the relief caused by tectonics that determine the manifestation of altitudinal zonality and latitudinal zonality;

- geosystems' groups (subgroups) - determining the development of radial and lateral water exchange, such as water-geochemical regime;

- geosystems' types (subtypes) - detected by soil types characteristics and classes of plant formations;

- geosystems' genera (subgenera) - reflecting spatial laws of exogeodynamic processes development and morphological forms of relief;

The structure features, formation, development and dynamics of the cultural landscapes of Mordovia reflect the metachronous nature of geosystems' development and interaction processes between nature and the processes of the central part of the Russian Plain economic development.

Climate dynamics and the effects of geosystems self-development determined changes in the states of landscape systems in the holocoen. Studies of paleogeographers (Galaasen et al., 2014) show that 10-12 thousand years ago there was a radical climatic change which determines the end of the last ice age and the beginning of the current interglacial period. Climate change is accompanied by a wide range of interrelated changes in global and regional geosystems: the weakening of the periglacial regime and the strengthening of the western air masses transport, an increase in the total amount of precipitation, the degradation of permafrost, the activation of thermokarst and solifluction processes; the formation of high floods on rivers, an increase in the proportion of lakes and marshlands, changes in the structure of vegetation, the formation of the anthropogenic factor of ecosystem regulation and the number of animals. Many features of landscape dynamics for the center of the Russian Plain are revealed in the works (Novenko et al., 2009; Isachenko, 2009; Makeev et al., 2021).

\section{RESULTS AND DISCUSSION}

Using the data of paleogeographers (Novenko et al., 2018), Table 1 shows the general nature of changes in the states of geosystems in the territory of Mordovia. The data analysis data shows that the current type of geo-systems functioning begins to be calculated from the middle holocoen.

\section{Geosystems classes}

The high landscape diversity of the region is determined by the geographical proximity of the stratum-tiered Volga upland 
and the stratum Oka-Don lowland, which invades the marginal part of the upland along the right bank of the Moksha River and the left banks of the Alatyr and the Sura rivers with relatively narrow ancient hollows of glacial water flow.

Table 1. Diagram of the dynamics of the Mordovia Republic geosystems in the holocoen (Novenko et al., 2018)

\begin{tabular}{|c|c|c|c|}
\hline $\begin{array}{c}\text { Absolute } \\
\text { chronology }\end{array}$ & Period & $\begin{array}{l}\text { Chrono } \\
\text { zone }\end{array}$ & Trends in changes in the state of geosystem types \\
\hline 1000 & $\begin{array}{c}\text { Late } \\
\text { holocoen }\end{array}$ & $\begin{array}{c}\text { Sub- } \\
\text { Atlantic }\end{array}$ & $\begin{array}{l}\text { Modern structure of geosystems; reduction of the forest-forming role of broad-leaved species, increase } \\
\text { of secondary forests and monocultural pine stands; anthropogenic transformation of geosystem }\end{array}$ \\
\hline 2500 & \multirow{2}{*}{$\begin{array}{c}\text { Middle } \\
\text { holocoen }\end{array}$} & Subboreal & $\begin{array}{l}\text { Medium-podzolic, turfy-carbonate (podsolized), gray forest, typical chernozems, carbonate, } \\
\text { chernozem-meadow. Reduction of the forest-forming role of broad-leaved species and older } \\
\text { trees, but strengthening of the role of pine; significant drying of swamps. Flora is enriched with } \\
\text { species peculiar to the meadow steppes. Depending on the lithogenic basis, the geosystems of } \\
\text { coniferous-broad-leaved, broad-leaved forests and meadow steppes are isolated. }\end{array}$ \\
\hline 4500 & & Atlantic & $\begin{array}{l}\text { Medium-podzolic, turfy-carbonate (podsolized), gley forest gray, hydromorphic and semi } \\
\text { hydromorphic analogues of chernozems, swampy soils of meadow raw; migration of broad- } \\
\text { leaved species to the watershed spaces of the Volga upland; increase in the diversity of pine-birch } \\
\text { forests, formation of mixed forests, oak forests on water-glacial plains of the Oka-Don lowland; } \\
\text { wide distribution of hydromorphic geosystems with alder trees in the river valleys. }\end{array}$ \\
\hline 8000 & $\begin{array}{c}\text { Early } \\
\text { holocoen }\end{array}$ & Boreal & $\begin{array}{l}\text { High proportion of lakes and marshlands, weakly podzolic, turfy-carbonate (podzolized and } \\
\text { leached), swampy soils of meadow row, carbonated chernozem; distribution of rare-coniferous } \\
\text { pine-birch forests. Reduction of tundra geosystems; formation of forest geosystems. }\end{array}$ \\
\hline 9500 & $\begin{array}{c}\text { Ancient } \\
\text { holocoen }\end{array}$ & Pre-boreal & $\begin{array}{l}\text { High proportion of lakes and marshlands; geosystems with hidden podzolic, turfy-carbonate, } \\
\text { meadow and swamp soils under sparse pine-birch forests, tundra steppes. }\end{array}$ \\
\hline 10300 & \begin{tabular}{|c|} 
Late \\
Pleistocene
\end{tabular} & Late Dryas & $\begin{array}{l}\text { Cryohyperzonal geosystems, intensive development of aeolian and cryogenic processes; } \\
\text { skrytopodzolic, turfy-carbonate, meadow and swamp soils; tundra steppe with xerophytic } \\
\text { herbaceous groupings and pine-birch open woods on water-glacial and ancient alluvial plains. }\end{array}$ \\
\hline $\begin{array}{l}11000 \\
12000\end{array}$ & & Alleroed & $\begin{array}{l}\text { Cryohyperzonal geosystems under conditions of permafrost degradation: tundrosteps adjacent to } \\
\text { pine-birch open woods. }\end{array}$ \\
\hline
\end{tabular}

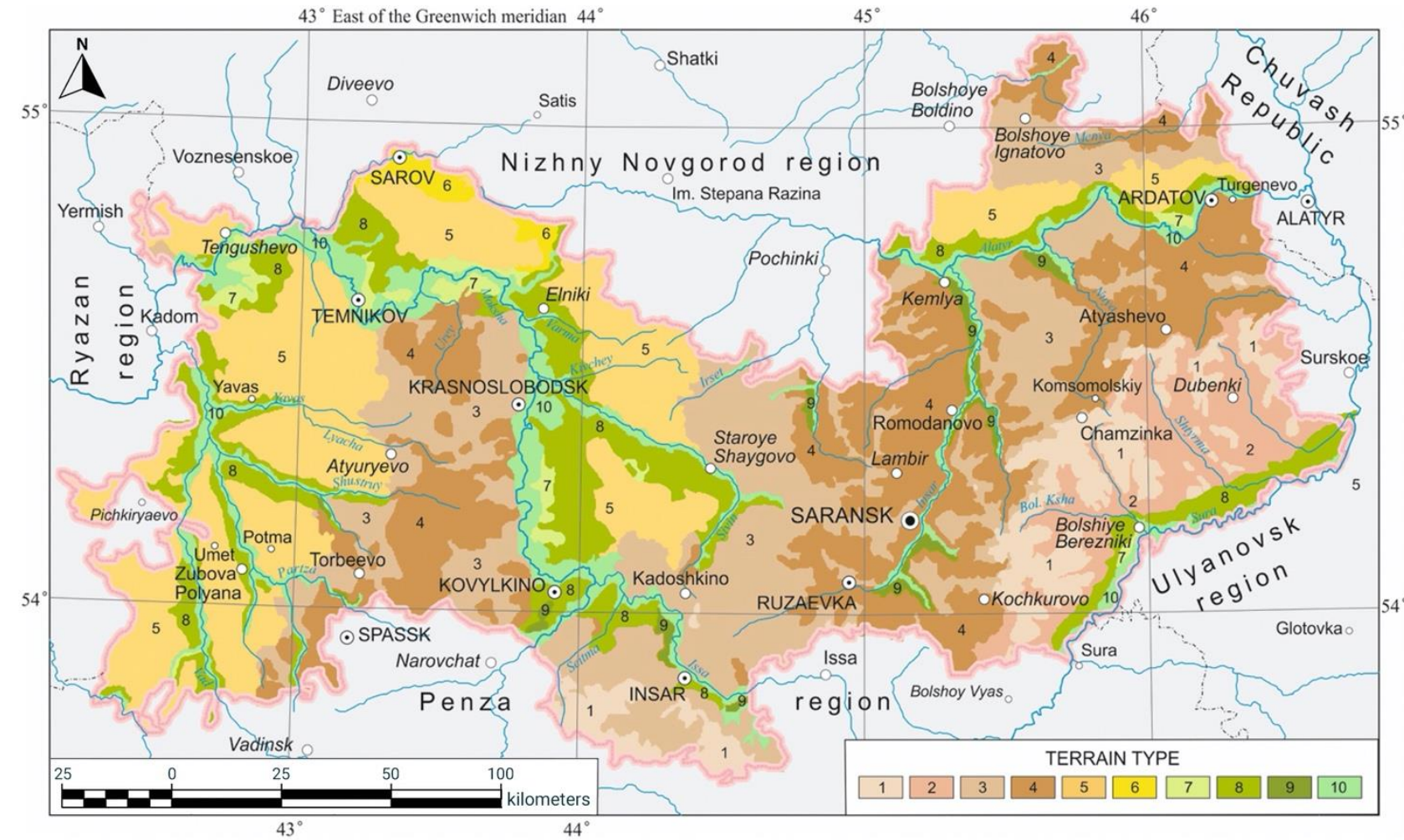

Figure 1. Modern types of geosystems (Yamashkin et al., 2012). Forest-steppe of the Volga upland: 1 - steppe upland oak forests with gray forest gravelly soils, selectively plowed; 2 - oak forests and shrub steppes with gray forest and black earth soils, selectively plowed; 3 - broadleaved forests with gray forest soils, selectively plowed; 4 - mixed-herbs grass steppes with chernozem, highly developed. Forest geosystems of the Oka-Don lowland and ancient hollows of glacial water flow: 5 - coniferous and mixed forests with turfy-podzolic soils, limited plowed; 6 - coniferous and mixed forests with taiga elements with podzolic soils, limited plowed. Valley geosystems: 7 - coniferous and mixed forests with podzolic, turfy-podzolic and poorly developed sandy soils, limited plowed; 8 - broad-leaved forests with gray forest soils and podzolic chernozem, selectively plowed; 9 - meadow and shrub steppes with chernozem, highly developed; 10 - floodplain complexes

\section{Geosystems class of the Volga upland forest-steppe}

The features of the landscape structure are determined by the distribution of siliceous-carbonate, carbonate and terrigenous sand-clay rocks of Meso-Cenozoic age. The development of slope paragenetic geosystems determined the natural change of forest types of landscapes on the remnant-watershed massifs to mixed-herbs grass steppes with chernozem on the lower near- 
valley areas of the slopes. Geosystems class of the forest province of the Oka-Don lowland was formed in ancient hollows of glacial water runoff that penetrate into the area of the Volga Upland with sandy lowlands. The wide distribution of sand deposits provides good filtration of precipitation. The heterogeneous composition of glacial sediments determines a large mosaic in the degree of hydromorphic geosystems. Their structure is dominated by coniferous and coniferous-deciduous forests with turfy-podzolic and gray forest soils (Figure 1). The most important waterways of the region are the Moksha and the Sura, which belong to the Volga basin, which served as a transcontinental route connecting the regions of Europe and Asia since ancient times. The ethnic groups settled along the rivers, and economic and cultural ties of the peoples were carried out.

Economic development, changes in life support systems and changes in the types of cultural landscapes of the region are developed in the context of global climate transformations in the holocoen that affect the state of regional and local geosystems.

\section{The stage of the appropriating economy}

In the Early Holocoen (Boreal and Pre-Boreal periods - 10-8 thousand years ago), tundra geosystems and sagebrush-haze steppes began to transform into pine-birch forest complexes because of climate warming. The sites belonging to the Paleolithic and Mesolithic are located on the dune-like elevations of the sandy ancient alluvial plains of the river Moksha valley and its tributaries, characteristic features of which in the places of ancient people residence were a high landscape diversity.

\section{The stage of residual forms of appropriating economy and the Neolithic revolution}

The Atlantic period (7.5-5.5 thousand years ago) is denoted by paleo geographers as the phase of the holocoen climatic optimum - the development of geosystems under conditions of further climate warming provided by moisture. On the Russian Plain, landscape differentiation is becoming more complex, and the modern structure of geosystems is being formed. As part of the forest - steppe geosystems of the Volga Upland, broad-leaved forests-oak, linden, elm - begin to dominate in the watershed spaces, which are replaced by mixed herbs grass steppes in the lower parts of the slopes; coniferous and mixed forests dominate on the water-glacial plains. Mesolithic and Neolithic monuments are usually located on sandy ancient alluvial terraces, riverine dunes rising above floodplain meadows and lakes. During the Subboreal period (4.5-2.5 thousand years ago), the climate becomes moderately warm and dry (Brown et al., 2017). Xerothermic conditions caused a reduction in swamp geosystems and an increase in the area of park oak forests and pine-birch forests. The Volosov and the Imerk cultures represent the eneolithic archaeological sites. They tend to be geosystems of mixed forests of sandy water-glacial and ancient alluvial plains. Features of material culture indicate the interaction of the Finno-Ugric tribes with the tribes of the Fatyanovo culture (the Indo-European branch of the ancient Balts). Features of ethnic groups' material culture represent their active employment in hunting, fishing, cattle breeding and agriculture.

\section{Evolution stage the pastoral-agricultural economic-cultural type of landscape development}

At the beginning of the sub-Atlantic period, the processes of climate cooling are manifested. The developing foreststeppe geosystems of the Volga Upland represented good pastures. Numerous archaeological sites testify their active development by the tribes of the Srubnaya, Andronovskaya, and Abashevskaya cultures. The sites are located in a wider range of landscapes than in the previous period, from forest to meadow-steppe. This is determined by the fact that the economic development of landscapes involves peoples whose culture has formed in different types of geosystems. Under their influence, the strengthening of the culture of the Bronze Age is noted. In the middle of the second millennium BC, the cultural landscape was enriched by the interaction of the local Finno-Ugric peoples with the tribes of the Srubnaya, Fatyanovo, Abashevo, and Balanov cultures that affected the development of agriculture and animal husbandry, and the creation of long-term settlements in all types of geosystems (Yamashkin et al., 2020). From the first millennium BC on the territory of modern Mordovia, the Finno-Ugric tribes of the Gorodets culture of early iron (culture of ancient settlements of matting ceramics) began to prevail. Their settlements are located on the main sides of river valleys and gullies. Such fortified settlements are numerous in the valleys of the Moksha and its tributaries, near Tengushevo, Narovatovo, Kargashino, Samozleika, Paevo villages, etc. At the same time with the settlements, there were big and small villages that did not have defensive structures. All zones of active economic development are characterized by high landscape heterogeneity. The highest density of settlements is typical for the areas of the confluence of rivers, contrasting landscape borders.

\section{The early stage of the Mordovian ethnos formation}

The climate of the center of the Russian plain from the IX-XI centuries is characterized by short-term climate fluctuations. The evolution of the ancient Mordva people material culture took place it was in the context of the development of contacts with the Slavs, Bulgars, Polovtsians, Khazars and other peoples. Interethnic contacts and self-development of local Finno-Ugric tribes led to the formation of the Mordovian ethnos and the development of its sub-ethnic groups - Erzya and Moksha.

\section{The formation of cultural landscapes during the period from the XVII to the middle of the XIX century}

The climate of the Russian plain center was characterized by relatively mild winters and cool summers. Paleo geographers (Büntgen et al., 2016) refer to this period as the "Little Ice Age". The defense lines that were built to protect the Moscow state became a characteristic element of the cultural landscape. At the intersections of fortifications with important roads, rivers or open spaces of meadow steppes, fortresses were built, many of which later became the cores of the developing settlement system, centers of trade, handicraft, religion, for example, Temnikov, Saransk, Insar, etc. Agricultural development of landscapes was accompanied by the development of rural settlements - big and small villages. To denote them the Mordva used the word 
"vele". The analysis shows that the formation of Mordovian settlements was determined both by the level of socio-economic development and the features of the settlement of patronymic groups, as well as by the nature of the surrounding landscape, the size and the topographic location of settlements in the area (Figure 2). When choosing a particular planning solution, the builders skillfully used various planning elements of the surrounding landscape - rough terrain, rivers, roads, etc. Rural architects, skillfully adapting to local conditions, developed stable traditional methods of architectural and planning composition of squares. It is noteworthy that closed areas in the settlements of Mordovia are very rare. The percentage of semi-closed areas is also small, but semi-open and uncovered areas predominate everywhere. Their composition uses an organic connection with the surrounding natural landscape, which is beneficial for the settlement. Orthodox churches and Muslim mosques are becoming important elements of residential landscapes. The Makarovsky, Sanaksar and Sarov monasteries are very famous.

The modern cultural landscape largely depends on the properties of geosystems and geographically inherits the centuriesold processes of economic development. Settlements, combining the place of residence, work, recreation and communication of the population, form a socio-territorial meso-environment for the development of ethno-cultural processes. The main parameters of the rural socio-settlement environment of interethnic interactions include: the number, population, density and functional types of settlements; types and forms of on-farm settlement; forms and ethno geographic structures of settlement areas, etc.

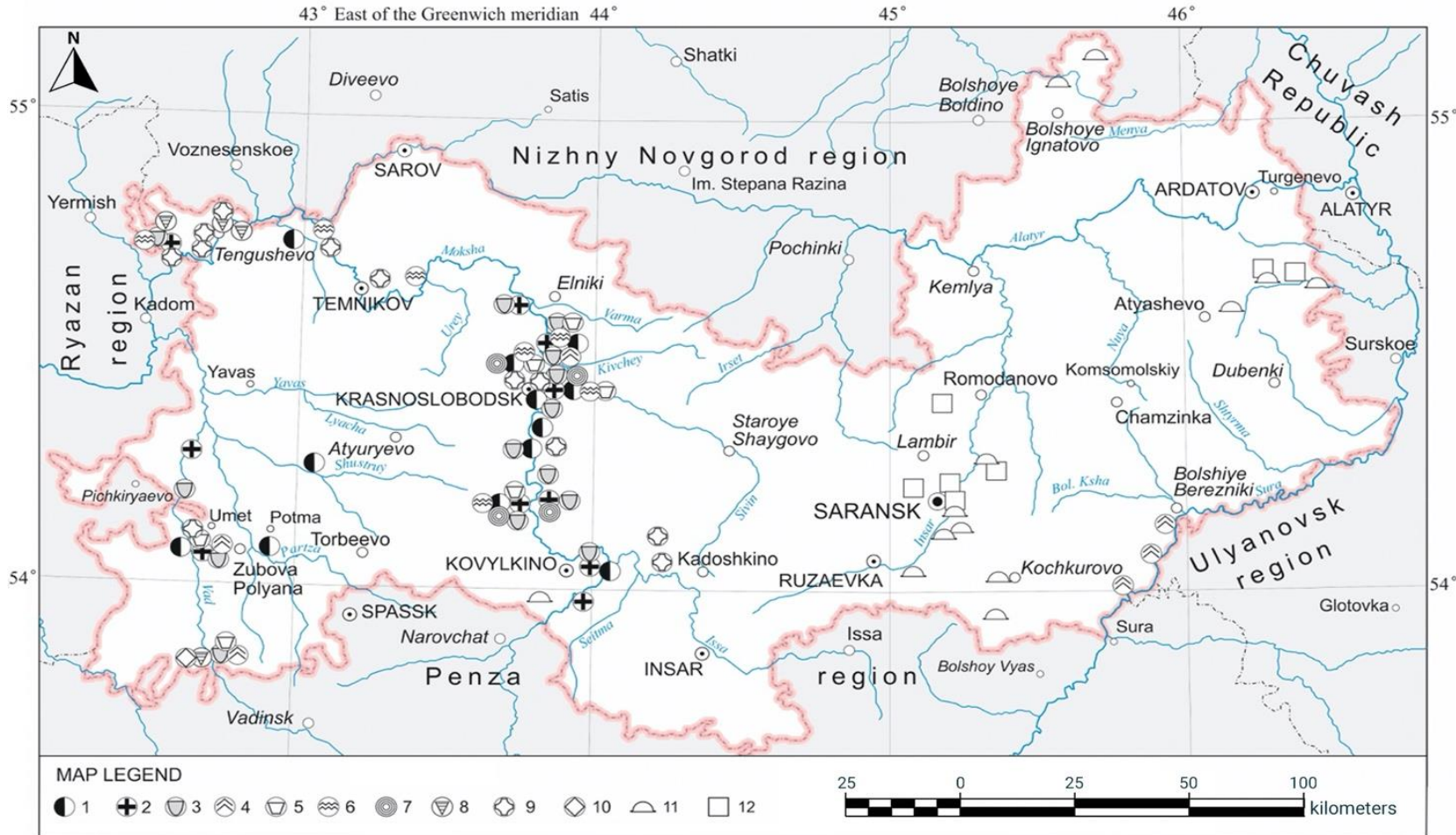

Figure 2. Monuments of archeology of the Republic of Mordovia (Yamashkin et al., 2012): 1 - Mesolithic; 2 - early Neolithic; 3 cultures of Matting Ceramics; 4 - early Eneolithic; 5 - Volosovsky; 6 - Imerk culture; 7 - Catacomb culture; 8 - Fatyanovo-Balanovo culture; 9 - Moksha culture; 10 - Abashevskaya culture; 11 - Mounds of the Srubnaya culture; 12 - Settlements of the Srubnaya culture

\section{The number and density of rural settlements}

At present, there are 1,261 settlements in the Republic of Mordovia, including 7 cities - 3 republican and 4 of regional subordination, 19 workers' settlements. The patterns of settlement distribution are consistent with the nature of landscape differentiation. The density of settlements increases from the geosystems of steppe upland oak forests with gray forest rubble soils of varying degrees to meadow-steppe landscapes with fertile chernozem from 0.012 to $0.070 \mathrm{units}^{\mathrm{k}} \mathrm{km}^{2}$. If in the settled upland oak forests, a significant share is made up of sparsely populated settlements, then in the meadow-steppe geosystems large settlements are more widespread (Table 2). The features of the most ancient periods of the development of the region are manifested in the settlement of ethnic groups: settlements with Moksha-Mordovian populations prevail in the Moksha River basin, and Erzya-Mordovian settlements dominate in the Sura basin. Settlements of Tatars gravitate towards meadow-steppe landscapes. Russian-dominated settlements are widespread. The geographical proximity of settlements of different ethnic composition influences the ethno-cultural processes, enriches the landscape appearance of the cultural landscape.

This is especially true for the areas adjacent to Moksha River and the central part of the Insar River basin.Residential landscapes form the economic (support) framework of the region, including a set of centers (cores of concentration) and edges (communications), which, on the one hand, integrates production functions, demonstrating the value of concentration, and on the other - defines the network of settlement, the core of the cultural landscape, ensuring the integration of natural and socioeconomic potential of the republic. The central link in the economic framework and cultural landscape of the Republic of Mordovia is Saransk, where about $30 \%$ of the population is concentrated. The administrative centers of districts, villages, and villages form a wide range of zones of interethnic interaction, and provide specific conditions for functioning of the ethnic culture component. It is also obvious that the more important the social-production and service functions performed by 
settlements, the more significant their role in the settlement system, the more intense ethno cultural processes in them. Ethnic groups in the republic live in close proximity, which is facilitated by the presence of compact forms of settlement areas. In some cases, various ethnic groups, compactly settled in areas, but functionally not united into agricultural enterprises, nevertheless are in close inter-settlement ties, which creates favorable conditions for their ethnic contacts. Therefore, it is important to take into account this type of interethnic interaction. The lifestyle of the rural population, to a greater extent than the lifestyle of the townspeople, reflects the specific features of the settlement environment. It is quite natural that the presence of small settlements and scattered settlements, among other things, limits the possibility of systematic interethnic communication. District centers unite the network of settlements into a territorial whole through a system of functional relationships, the strength and saturation of which depend on their status: the higher it is, the more attractive they have. Possessing multifunctionality, they are the place of the most intensive interethnic contacts, differentiated depending on the history of development, the state of the transport infrastructure and forms of settlement areas of ethnic groups. In the process of landscapes economic development, a wide range of objects of natural and historical heritage was formed, including more than 2100 monuments of nature, history and culture (Figure 3), 953 of them are protected by the state: nature reserve, natural monuments, ethnographic centers, places associated with the development of folk arts and crafts, the life of outstanding historical personalities.

Table 2. Distribution of settlements by types of geosystems (2020) (Yamashkin et al., 2020)

\begin{tabular}{|c|c|c|c|c|c|c|c|c|c|c|c|}
\hline \multirow[b]{2}{*}{$\begin{array}{l}\text { Grouping } \\
\text { geosystems }\end{array}$} & \multirow{2}{*}{$\begin{array}{c}\text { Number of } \\
\text { settlements, } \\
\text { units }\end{array}$} & \multirow{2}{*}{$\begin{array}{c}\text { Settlements share } \\
\text { from their number } \\
\text { in the region \% }\end{array}$} & \multirow{2}{*}{$\begin{array}{l}\text { Population } \\
\text { density, } \\
\text { units } / \mathrm{km}^{2}\end{array}$} & \multicolumn{8}{|c|}{ Percentage of settlements with different population levels, \% } \\
\hline & & & & $\begin{array}{c}\text { less } \\
\text { than } 26\end{array}$ & $26-50$ & $\begin{array}{l}51- \\
100\end{array}$ & $\begin{array}{c}101- \\
200\end{array}$ & $\begin{array}{c}201- \\
500\end{array}$ & $\begin{array}{l}501- \\
1000\end{array}$ & $\begin{array}{l}1001- \\
2000\end{array}$ & $\begin{array}{c}\text { more than } \\
2000\end{array}$ \\
\hline \multicolumn{12}{|c|}{ Geosystems of the Volga upland forest-steppe } \\
\hline $\begin{array}{l}\text { Steppe upland } \\
\text { oak forests }\end{array}$ & 19 & 1.51 & 0.012 & 47.37 & 5.26 & 5.26 & 5.26 & 21.05 & 15.79 & 0.00 & 0.00 \\
\hline $\begin{array}{l}\text { Broad-leaved } \\
\text { forests }\end{array}$ & 141 & 11.18 & 0.041 & 39.01 & 9.93 & 9.22 & 9.93 & 23.40 & 4.96 & 0.00 & 3.55 \\
\hline $\begin{array}{l}\text { Oak forests and } \\
\text { shrub steppes }\end{array}$ & 352 & 27.91 & 0.053 & 33.52 & 6.25 & 12.22 & 12.78 & 23.86 & 7.67 & 1.42 & 2.27 \\
\hline $\begin{array}{l}\text { Mixed herbs } \\
\text { grass steppes }\end{array}$ & 509 & 40.36 & 0.070 & 29.47 & 10.81 & 9.23 & 15.72 & 19.84 & 8.25 & 3.14 & 3.54 \\
\hline \multicolumn{12}{|c|}{ Geosystems of the Oka-Don lowland forest province } \\
\hline $\begin{array}{l}\text { Coniferous and } \\
\text { mixed forests }\end{array}$ & 240 & 19.03 & 0.032 & 42.92 & 10.00 & 10.83 & 11.67 & 14.17 & 3.75 & 1.67 & 5.00 \\
\hline
\end{tabular}

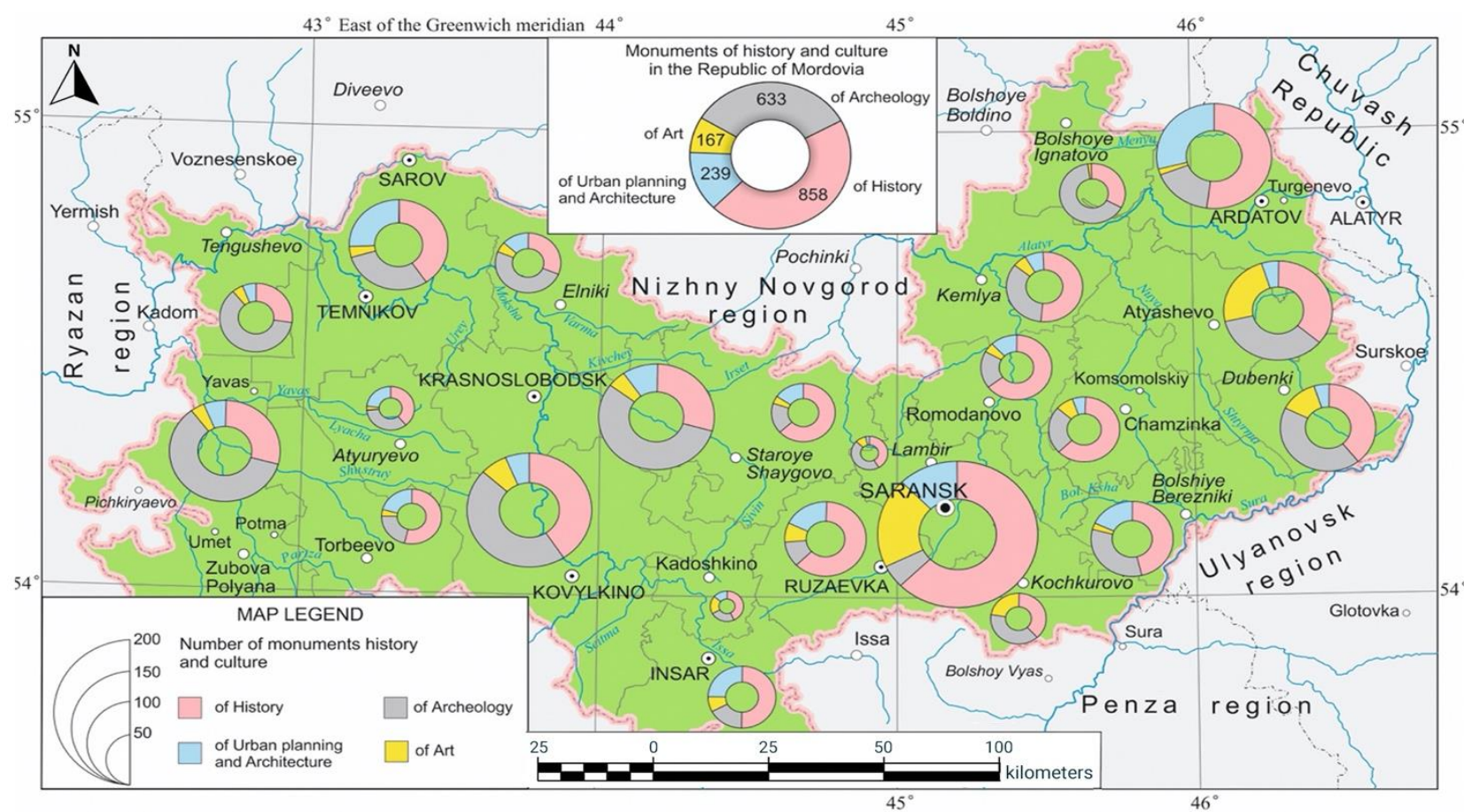

Figure 3. Historical monuments in the cultural landscape (Yamashkin et al., 2012)

\section{CONCLUSIONS}

The introduction of digital technologies in the field of Earth sciences is an actively developing scientific direction focused on solving problems of optimizing the interaction of nature and society. GIS technologies in the field of tourism and recreation activities, business structures, and the daily life of the general population makes it possible to increase the efficiency of solving the problems of planning sustainable landscapes. The study of cultural landscapes formation can be done successfully by means of using digital infrastructures of spatial data, providing the following directions of research development: development of databases of spatio-temporal organization of geosystems as the basis for the population's life support and cartographic modeling of patterns of geosystems economic development. 
The regional GIS "Mordovia" and geoportal "Natural and Historical Heritage of the Republic of Mordovia" (https://tourismportal.net/) contain an interactive system of thematic maps and databases that reveal the peculiarities of nature, population, economy, cultural heritage, and the development of environmental situations of the region: a wide range of objects of natural and historical heritage, including more than 2100 monuments of nature, history and culture, more than 900 of them are protected by the state: nature reserve and monuments, ethnographic centers.

Cultural landscapes of Mordovia were formed in the process of centuries-old economic development of geosystems. As the most important components, they include high landscape diversity, cultural objects of peoples with unique development paths. The cohabitation of Mordovians, Russians, Tatars, and representatives of other ethnic groups on the same territory naturally affects the mutual enrichment of cultural traditions, forms a single cultural landscape. The latter is differentiated into local ecological, socio-economic systems that differ in the ecological conditions of population's life support and contain objects of natural and historical heritage. The development of comprehensive geographical assessment of natural and cultural heritage objects, the creation of a methodology for systematization, geoinformation mapping and the effective use of diverse information about the region to ensure the active development of tourist and recreational activities should be carried out in compliance with the genetic, historical and systemic principles in the study of the region. Together, they provide the creation of a concept of scientific, educational, environmental and health tourism development.

\section{Acknowledgement}

The reported study was funded by RFBR, project number 20-37-70055.

\section{REFERENCES}

Adhika, I.M., \& Putra, I.D. (2020). Reinvigorating Cultural Landscapes for Planning Cultural Tourism in Bali. GeoJournal of Tourism and Geosites, 33(4spl), 1462-1469. https://doi.org/10.30892/gtg.334spl03-594

Begovatkin, A.A. (2017). Republic of Mordovia. In Arheologicheskaya karta Rossii. [Archaeological map of Russia], 340-388. IA RAS, Moscow, Russia, (in Russian).

Brown, K.J., Hebda, N.J., Conder, N., Golinski, K.G., Hawkes, B., Schoups, G., \& Hebda, R.J. (2017). Changing climate, vegetation, and fire disturbance in a sub-boreal pine-dominated forest, British Columbia, Canada. Canadian Journal of Forest Research, 47(5), 615-627.

Büntgen, U., Myglan, V.S., Ljungqvist, F.C., McCormick, M., Di Cosmo, N., Sigl, M., \& Kirdyanov, A.V. (2016). Cooling and societal change during the Late Antique Little Ice Age from 536 to around 660 AD. Nature geoscience, 9(3), 231-236. https://doi.org/10.1038/ngeo2652

Dunets, A.N., Vakhrushev, I.B., Sukhova, M.G., Sokolov, M.S., Utkina, K.M., \& Shichiyakh, R.A. (2019). Selection of strategic priorities for sustainable development of tourism in a mountain region: concentration of tourist infrastructure or nature-oriented tourism. Journal of Entrepreneurship and Sustainability Issues, 7(2), 1217. https://doi.org/10.9770/jesi.2019.7.2(29)

Galaasen, E.V., Ninnemann, U.S., Irval1, N., Kleiven, H.K.F., Rosenthal, Y., Kissel, C., \& Hodell, D.A. (2014). Rapid reductions in North Atlantic Deep Water during the peak of the last interglacial period. Science, 343(6175), 1129-1132. https://doi.org/10.1126/science.1248667

Gordon, J.E. (2018). Geoheritage, geotourism and the cultural landscape: Enhancing the visitor experience and promoting geoconservation. Geosciences, 8(4), 136. https://doi.org/10.3390/geosciences8040136

Hall, C.M., \& Page, S.J. (2002). The Supply of Recreation and Tourism. In The geography of tourism and recreation: Environment, place and space, 87-130, Routledge, London, United Kingdom. https://doi.org/10.4324/9780203246276

Isachenko, T. (2009). Cultural landscape dynamics of transboundary areas: A case study of the Karelian Isthmus. Journal of Borderlands Studies, 24(2), 78-91. https://doi.org/10.1080/08865655.2009.9695729

Kagansky, V.L. (2001). World of cultural landscape. In Kulturnyj landshaft i sovetskoe obitaemoe prostranstvo [Cultural landscape and Soviet habitable space], 23-135, UFO, Moscow, Russia, (in Russian).

Makeev, A., Rusakov, A., Kurbanova, F., Khokhlova, O., Kust, P., Lebedeva, M., \& Mihailov, E. (2021). Soils at archaeological monuments of the Bronze Age - a key to the Holocene landscape dynamics in the broadleaf forest area of the Russian Plain. Quaternary International, 590, 26-47. https://doi.org/10.1016/j.quaint.2020.09.015

Nikolaev, V.A. (2000). Landshaftovedenie. Seminarskie i prakticheskie zanyatiya [Landscape studies. Practical and seminary classes], Moscow university Publishing House, Moscow, Russia, (in Russian).

Novenko, E.Y., Volkova, E.M., Nosova, N.B., \& Zuganova, I.S. (2009). Late Glacial and Holocene Landscape Dynamics in the Southern Taiga Zone of East European Plain According to Pollen and Macrofossil Records from the Central Forest State Reserve (Valdai Hills, Russia). Quaternary International, 207(1-2), 93-103. https://doi.org/10.1016/j.quaint.2008.12.006

Novenko, E.Y., Mazei, N.G., Kupriyanov, D.A., Volkova, E.M., \& Tsyganov, A.N. (2018). Holocene dynamics of vegetation and ecological conditions in the center of the East European Plain. Russian Journal of Ecology, 49(3), 218-225. https://doi.org/10.1134/S1067413618030062

Ringer, G.E. (2013). Destinations. In Destinations: Cultural landscapes of tourism, 49-174, Routledge, London, United Kingdom.

Sochava, V.B. (1978). Evolution and dynamics of geosystems. In Vvedenie v uchenie o geosistemah [Introduction to the Study of Ecosystems], 106-127, Nauka. Sibirskoe otdelenie, Novosibirsk, USSR, (in Russian).

Terkenli, T.S. (2001). Towards a theory of the landscape: the Aegean landscape as a cultural image. Landscape and urban planning, 57(3-4), 197-208. https://doi.org/10.1016/S0169-2046(01)00204-3

Vos, W., \& Meekes, H. (1999). Trends in European cultural landscape development: perspectives for a sustainable future. Landscape and urban planning, 46(1-3), 3-14.

Yamashkin, A.A. (2008). General characteristics of the cultural landscape of the Republic of Mordovia. In Prirodnoe i istoricheskoe nasledie culturnogo landshafta Mordovii [Natural and historical heritage of the cultural landscape of Mordovia], 22-47. Mordovia State University Publishing House, Saransk, Russia, (in Russian).

Yamashkin, A.A., Yamashkin, S.A., Aksyonova, M.Y., Cimbaljević, M., Demirović, D., Vuksanović, N., \& Milentijević, N. (2020). Cultural landscapes space-temporal systematization of information in geoportals for the purposes of region tourist and recreational development. Geojournal of Tourism \& Geosites, 29(2), 440-449. https://doi.org/10.30892/gtg.29205-480

Yamashkin, A.A. (Ed.). (2012). Population and Social Infrastructure. In Geographical Atlas of the Republic of Mordovia, 74-103, Mordovia State University Publishing House, Saransk, Russia, (in Russian).

*** Geoportal of the Natural and Cultural Heritage of Mordovia, accessed 21.08.2021. https://tourismportal.net/ 